University of Nebraska - Lincoln

DigitalCommons@University of Nebraska - Lincoln

Faculty Publications: Department of Teaching, Department of Teaching, Learning and Teacher Learning and Teacher Education

Education

2018

Developing multilingual pedagogies and research through language study and reflection

Theresa Catalano

Madhur Shende

Emily K. Suh

Follow this and additional works at: https://digitalcommons.unl.edu/teachlearnfacpub

Part of the Curriculum and Instruction Commons, and the Teacher Education and Professional

Development Commons

This Article is brought to you for free and open access by the Department of Teaching, Learning and Teacher Education at DigitalCommons@University of Nebraska - Lincoln. It has been accepted for inclusion in Faculty Publications: Department of Teaching, Learning and Teacher Education by an authorized administrator of DigitalCommons@University of Nebraska - Lincoln. 


\title{
Developing multilingual pedagogies and research through language study and reflection
}

\author{
Theresa Catalano, Madhur Shende, and Emily K. Suh
}

\author{
Department of Teaching, Learning and Teacher Education, \\ University of Nebraska-Lincoln, Lincoln, NE, USA \\ Correspondence - Theresa Catalano, tcatalano2@unl.edu, Department of Teaching, Learning \\ and Teacher Education, University of Nebraska-Lincoln, Henzlik 27, Lincoln, NE, USA
}

\begin{abstract}
Globalization and increased transnational migration underscore the need for educational responses to multilingualism and multilingual discourses. One way to heighten awareness of multilingual pedagogies (while simultaneously providing data for multilingual research) is the use of reflective language study and journaling by language educators/researchers. The purpose of this collaborative autoethnography, which focuses on the United States, is to demonstrate how this can be accomplished in language teacher education courses to help raise awareness and interest of how to capitalize on students' linguistic and cultural resources. Data for this study included three participant/researcher journals and observational notes from collaborative discussions among researcher/participants about the lived experiences of multilingual language educators as they studied a new language and wrote about their experiences. Findings reveal possibilities for future research in cross-linguistic transfer as well as the teaching of multilingual pedagogies and issues of social justice as it relates to multilingual education.
\end{abstract}

Keywords: Reflective practices, multilingualism; journaling, language teacher education/research

Published in International Journal of Multilingualism, Vol. 15, No. 1 (2018), pp 1-18. doi:10.1080/14790718.2016.1181633

Copyright (C) 2016 Informa UK Ltd, Taylor \& Francis Group. Used by permission. Submitted 11 November 2015; accepted 11 April 2016; published 13 May 2016. 


\section{Introduction}

Recent current events and the continual movement of multilingual transnationals underscore the need for educational responses to multilingualism/linguistic diversity. However, despite globalization and increased migration worldwide, studies show that the 'engagement of language educators with issues of diversity and globalization is limited' (Liddicoat, Heugh, Jowan Curnow, \& Scarino, 2014, p. 270) and there is a general lack of awareness or interest, specifically in wealthy countries that are receiving inward migration, in the language backgrounds of the student body 'which has become very international as well as linguistically and culturally diverse' (Pauwels, 2014, p. 307). In addition, there is a lack of understanding of the multidimensional nature of multilingualism and multilingual students (Ruiz de Zarobe \& Ruiz de Zarobe, 2015). In the United States, this lack of response to the increased linguistic/cultural diversity of students is compounded by the presence of monolingual language ideologies that have historically shaped education policies and practices in the United States over time.

Taking a 'language as a resource' (Ruiz, 1984) and 'multilinguality' approach, which treats the multilingual nature of learners as a resource for ongoing linguistic and cognitive growth and aims to enhance the status of subordinate languages (Agnihotri, 2014, p. 365; Ruiz, 1984), this paper seeks to explore how language teacher educators can raise awareness and interest in the field of multilingualism regarding students' linguistic and cultural resources. In order to do this, the paper will demonstrate how practicing language educators (and one language teacher educator), learning a new language and simultaneously documenting this learning process through journaling, made connections to multilingual discourses and pedagogies in their course on multilingualism. In addition, the paper will establish the potential of this activity for producing high-quality qualitative research in the field.

Although language teachers are often successful language learners themselves, our own teaching experiences lead us to believe that teachers stop or slow down the language learning process and rarely take on studying a new language once they begin teaching. Furthermore, we found no research that presents evidence that teachers document or reflect on their language study if they do take up a new 
language. However, research has shown that teachers develop by studying their own practice, collecting data and using reflective processes as a basis for evaluation and change (Loughran, 2002; Mann, 2005). Hence, this collaborative auto-ethnographical study (Ellis, 2009; Ellis \& Bochner, 2000) will illustrate how multilingual language teachers themselves engaged in additional language acquisition (while studying third or additional languages) as part of a course on multilingualism and education for Masters and doctoral students in education programs at the University of Nebraska-Lincoln in the United States. Although the course was not designed solely for multilingual teachers, all students were multilingual with current or previous teaching experience in the fields of math, science, foreign/second language, second language acquisition and pre-service teacher education. The course, and this paper, were motivated by the belief that 'increasing awareness and explicit recognition' of multilingualism's complexity allows for a more comprehensive understanding that will yield 'practical results' in language pedagogy (Aronin \& Singleton, 2012, p. 185) and research.

\section{Conceptual framework}

\section{Language ideologies, policies, and education in the United States}

There is a global need to respond to multilingual transnational learners with multilingual pedagogies, and more attention needs to be dedicated to the educational needs of migrant students that bring with them linguistic repertoires that are often overlooked and undervalued in their schooling experiences. In the United States, this need is even greater than in many areas of the world because monolingual (as opposed to multilingual) ideologies still prevail and shape educational policies, often resulting in unequal education for minority language students. To contextualize the need for this study, we begin with

a brief historical context of education for minority language students in the United States.

According to de Jong (2013), language education policies in the United States have 'varied significantly over time, and been shaped by both assimilationist (monolingual) and pluralist (multilingual) views 
of the role of linguistic and cultural diversity in schools' (p. 98). Beginning with pluralist discourses at the time of European colonization in North America to early assimilationist discourses in the late nineteenth and early twentieth centuries, de Jong classifies current language discourse as 'assimilationist' with 'pluralist edges' (p. 98). Since the 1980 s, more than 20 states have declared English as the official language (Schildkraut, 2001) providing evidence of the emergence of 'a modern Americanization movement' and 'a return to a strong assimilationist discourse' in the United States (de Jong, 2013, p. 104). These assimilationist discourses shaped language policies in the early 2000s such as California's Proposition 227 and Arizona's 203, which represent the 'English only' movement and present monolingualism in the contexts of violence and heroism in which monolingual discourses prevail (Johnson, 2005). At the same time, McCarty (2004), Ricento (2005) and others note a paradox in American schools in which value has been placed on 'foreign' language instruction while at the same time indigenous and immigrant minority languages are devalued. Building on this finding, Valdez, Delavan, and Freire (2014) note the recent shift in US language education policy discourses from an equity/heritage policy framework that emphasizes language rights and educational equity to a global human capital (GHC) policy framework, that is based on 'neoliberal interpretations' of education as an investment (p. 3). This shift represents a change in the audience to which language education programs are primarily marketed, and the authors caution against the way in which GHC value discourses can overpower and overshadow equity (Valdez et al., 2014).

Back in 1984, Richard Ruiz, in his seminal work on language orientations, proposed a language-as-resource orientation that would encourage the study of foreign languages AND the continued study of languages represented by minority communities. Through this lens, language minority communities would be seen as 'important sources of expertise' (p. 28) and the status of subordinate languages would be enhanced. However, as Ricento (2005) points out, current discourse on language policy (including heritage language policy) focuses 'on instrumental values of heritage language while ignoring (or downplaying) the human beings, communities and socio-political dimensions of language acquisition, use and loss in the U.S.' (p. 362). Unfortunately, these assimilationist approaches to language 
education still dominate US language education media discourse, and shape the way the public views language education. Hence, one of the purposes of this study is to reveal how language teachers/educators negotiate and recognize these ideologies in their own language learning through the use of reflective journals, and to inspire multilingual language-as-resource discourses and pedagogies that counter these assimilationist ideologies.

\section{Cross-linguistic influence}

Besides raising awareness of teachers to the possibility of multilingual pedagogies and ideologies in their own teaching, an aim of this study is to explore potential for future qualitative research in the area of multilingualism through language study by language educators. One of the principle areas in which this potential for research was found in the study (to be discussed in the Findings section) was in the area of cross-linguistic influence (CLI). CLI refers to the way in which other languages known by a learner can influence target language learning (e.g. 'transfer, interference, avoidance, borrowing') (De Angelis, 2007, p. 19). In order to understand how our findings reflect and support current research in this field, we must first provide a brief summary of current research in this area, particularly in regards to areas which surfaced in the participant journals of this study.

Integrated linguistic systems. Current research supports the theory of integrated languages within the bi/multilingual mind (Aronin \& Singleton, 2012; Canagarajah, 2011; Cenoz, 2013; Hall et al., 2009; Ruiz de Zarobe \& Ruiz de Zarobe, 2015). Through research on translanguaging (defined by Canagarajah as 'the ability to shuffle between languages, treating the diverse languages that form their repertoire as an integrated system' (2011, p. 401), support for a more holistic view of multilingualism has been put forward. This holistic view has replaced independent conceptions of monolingual competences by 'the assumption of an integrated bi/multilingual competence' (Ruiz de Zarobe \& Ruiz de Zarobe, 2015, p. 399). As a consequence, this new understanding of how languages are processed in the brain has translated into a trend of teaching practices that take an integrated approach to teaching in which languages are treated as a whole unit rather than separate entities. 
Affective factors. Research suggests that previous language learning experiences can also contribute to additional language acquisition. Some studies have found that foreign language anxiety (FLA) may increase as learners acquire additional languages and proficiency (MacIntyre \& Gardner, 1991) and can have a significant and increasingly negative impact on student performance for intermediate and advanced language learners (Saito \& Samimy, 1996). Learner perceptions regarding the differences between the target language and L1 have also been found to increase learner anxiety (Jorden \& Walton, 1987). Beginning learners may lack sufficient language learning experiences for anxiety to affect their performance (Saito \& Samimy, 1996); in addition, multilinguals have been found to outperform bilinguals based on their ability to draw from their previous language learning experiences (Keshavarz \& Astaneh, 2004; Klein, 1995).

Linguistic distance and foreign language tagging. The theory of transferability (Kellerman, 1979) states that learner intuition about how related phenomena are influences learner choices about their transferability. When multilinguals make linguistic choices in communication, they must consider many factors in deciding which forms/ lexical items to choose. In doing so, research has found that multilinguals often consider the linguistic distance (i.e. how closely related, or the perception of how closely related the languages are to each other) in the sense that the closer they believe the languages to be, the more they will attempt to use the same words across languages, facilitating CLI and acquisition (Ringbom, 2001). Furthermore, cognates have been found to trigger CLI (Nation, 1990), and research has found that true cognates are accessed and translated faster than noncognates (Cenoz, Hufeisen, \& Jessner, 2001; de Groot, 1992; Kroll \& Stewart, 1994). On the other hand, target languages which are perceived to have great linguistic distance from the L1 can be tagged as 'foreign', decreasing learners' reliance upon previously acquired languages and their conscious and unconscious willingness to draw upon that knowledge (Burton, 2013; De Angelis, 2005; Kellerman, 1979; Odlin, 2003). Hence, although recent research views languages in multilingual learners' repertoires as whole and integrated units, research in the field of CLI is still helpful in explaining errors and successes in daily language use, and is thus highly relevant to this study. 


\section{Reflective practices in language teacher education}

A large body of research has documented the value of reflective practices such as journaling in the learning to teach process (Akbari, 2007; Farrell, 2007, 2011, 2013; Loughran, 2002; Mann, 2005). For language teachers in particular, Richards and Lockhart (1994, p. 6) suggest keeping a journal as a basis for critical reflection and a way to 'capture the thoughts of and reactions to' language learning events and relate them to teaching. The authors suggest that journals be kept on a regular basis, written immediately following a lesson and reviewed afterwards. In addition, the authors suggest that the learners share their journals regularly with classmates. According to Farrell, 'Reflecting on practice can help teachers move from a level where they may be guided largely by impulse, intuition or routine, to a level where their actions are guided by reflection and critical thinking' (2013, p. 465). Teachers must also learn to subject their own beliefs about the teaching and learning process to a critical analysis, and thus take more responsibility for their classroom actions because the very act of writing allows teachers time to organize their thoughts so that they can 'consciously explore and analyze their practice' (Farrell, 2013, p. 470). Farrell (2011) also found that English as a second language (ESL) teachers engaging in reflective practices such as journaling can become more aware of their identity roles and how they have been shaped over time. In addition, the sharing of journals in reflective conversation groups can help teachers reason about their teaching experiences. According to Akbari (2007), not all types of reflective practices are equal, and more attention needs to be paid to critical aspects of teaching that result in the improvement of the society in which language teachers live. Akbari also argues that what is being taught in most teacher training programs is how to reflect, but not what to reflect on. Thus, reflecting on the reflection itself can lead to better results.

While many studies document the use of journals to reflect on language teaching (e.g. Farrell, 2013; Richards \& Lockhart, 1994), no studies were found that document the use of journals to track language learning by language educators. One study was found that did document the use of reflection on language learning in multilinguals, although the participants were language students, not language teachers. Cohen (1995) explored what it means to think in a target language 
while considering the role of target-language thinking in improving language ability. This was accomplished by asking college English as a foreign language (EFL) students in a mini-survey to think through their L1s while performing target language tasks and to discuss factors which determined both unplanned and planned use of more than one language for thinking. Although this study did conclude that asking multilinguals to talk about what they were thinking can be a valuable exercise, it did not provide opportunities for learners to write about their experiences directly after being engaged in language lessons.

In summary, research related to reflective practices point to journaling and group discussions as productive ways of learning about language learning and teaching. The present paper fills a gap in this area by showing the research and pedagogy possibilities that can arise from language teachers/researchers engaged in simultaneous language learning and journaling.

\section{Research questions}

In this study, reflective journals documenting the students' language progress in relation to multilingual educational issues and intellectual debate reflecting on the journals serve as the data, touching on a number of current themes in the field and seeking to answer the following research questions:

(1) What can language teachers gain by participating in a language study and journal activity?

(2) What can the field of multilingual research gain through language study and journaling?

\section{Method}

The qualitative research method selected for this study is collaborative autoethnography (CAE). CAE is autobiographical, engaging multiple authors (who are also the participants) with diverse perspectives in the self-reflexive examination of their own assumptions and perspectives (Chang, 2013). CAE uses the researchers' personal experiences 
as primary data with the intention of understanding social phenomena (in this case, what it means to be a multilingual language learner when one is also a language teacher and language researcher). In addition, CAE involves researchers 'collecting their autobiographical materials to analyze and interpret their data collectively to gain a meaningful understanding of sociocultural phenomena reflected in their autobiographical data' (Chang, Wambura Ngunjiri, \& Hernandez, 2013, p. 24). In this way, the detailed experiences of participants in the language study and journal become an impetus for understanding the language learning process from the perspective of multilingual students in addition to reflecting upon the value of journaling during language learning. Because the researchers in this study are also the participants, institutional review board approval was not necessary.

\section{Data collection and analysis}

Data consisted of participant journals and observation notes from participant collaborative sessions discussing the journal and language study experience.

Seven journal entries were collected from each of the participants between the dates of 3 February and 10 March 2015, which corresponded to the time frame of the language study. Collaborative discussions occurred on 12 September 2015 and in subsequent online conversations during and after the writing process. Participants were directed to follow a language journal template to structure their reflection, and the activity required students to reflect on their language lesson for the week, connecting it to what they were learning in class regarding multilingualism. After the course was completed, journals from the researcher/participants were uploaded as one file to MAXQDA and coded thematically through selective open coding (Saldaña, 2013) for recurring themes. Once themes were determined by the first author, researcher/participants met to discuss themes. In this way, participant/researchers attempted to listen to each other's voices, probing deeply to examine their own 'hidden assumptions' and reach a 'deeper level of analysis' (Chang, 2013, p. 28). The researcher/participants then examined, discussed and categorized important comments from the journals together, re-working the themes and categorizing relevant comments. Findings were then organized according to 
these new themes, including direct quotations from researcher/participant journals and discussions of these themes from collaborative discussion sessions.

\section{Researcher/participant positioning and profiles}

The researcher/participants' language profiles and relevant information about their language and teaching backgrounds are given in

\section{Table 1.}

First author. First author is an assistant professor of second language education/applied linguistics and instructor of the course investigated for this paper. She grew up as a monolingual English speaker. She learned Spanish in high school and added Italian as a college student as well as one year of French. Later, she taught English for one year in Turkey, which led to her initial study of Turkish, and then taught Italian for 12 years at the university level. When her teenage daughter received a scholarship to study in Germany, she engaged in a six-month self-study of German, culminating (and ending shortly afterward) in a trip to Germany to visit her daughter. She chose to study Turkish, due mainly to her future plans to return to Turkey and the availability of a tutor, which she studied with for one hour a week during the seven weeks this time period.

Table 1. Participant language profile.

\begin{tabular}{lccc} 
Author-participants & L1s & L2s (in order of acquisition) & L3 \\
\hline First author & English & Spanish & Turkish \\
& & Italian & \\
& & French & \\
& & German & \\
\hline Second author & Marathi & Turkish & Chinese \\
& Hindi & Sanskrit & \\
& English & French & \\
& & Japanese & French \\
\hline Third author & English & Spanish & \\
& & Spanish & \\
\hline
\end{tabular}

Bolded languages are L1s of the participants or L2s in which the participant is proficient (as measured by a score of Advanced Low on the ACTFL oral proficiency interview or equivalent). 
Second author. Second author is a PhD student interested in second language education. Prior to being a doctoral student, she taught (at various time periods) French, Sanskrit, Hindi, English and Marathi. Her mother tongue is Marathi, but she grew up as a multilingual speaker simultaneously learning Hindi and English and studying in an English medium school where Hindi and Marathi were also taught as 'subjects' and Sanskrit was added to this list in the 8th grade. She later studied French (in which she is a proficient speaker) and one year of Japanese. She chose Chinese for her language study because a classmate requested they do a Hindi-Chinese language exchange (tutoring each other), and she had some interest in Chinese due to her experience with Japanese.

Third author. Third author is a developmental English instructor, who has also taught ESL/EFL and family literacy, and a PhD candidate whose assistantship includes teaching second language acquisition and ESL methods. An L1 speaker of English, she began learning Spanish at a young age from her father. After five years of formal Spanish study, she took a Korean class in college, met and married a Korean-American and moved to Korea to teach EFL. She began her study of French motivated by a summer study-abroad trip she was leading for community college students and her belief that years of receptive Spanish would assist her with vocabulary and grammar acquisition in French. To learn French, she used the app, DuoLingo, which she supplemented with www.youtube.com videos of French cooking lessons and cartoons.

\section{The setting}

The language study and journal activity detailed in this paper was just one activity within a course for graduate students at the University of Nebraska-Lincoln in the United States. This course was designed as part of a larger effort to prepare Nebraska teachers (and future teacher educators) to work with linguistically and culturally diverse students. Nebraska ranks among states in the United States experiencing the highest growth rates of English learners with a 242.2\% increase over the past 20 years (Pandya, McHugh, \& Batalova, 2011), an increase which affects rural as well as urban areas. This dramatic 
increase in multilingual students explains to a certain extent why teacher preparation for culturally/linguistically diverse classrooms has become a priority in Nebraska as well as regionally and nationally. However, despite this increase, attention to students' home languages is largely absent, and there is little to no space in most class curricula across the state (with the exception of 8 of the state's 1294 public schools offering dual-language Spanish programs) for these languages (Education Bug, 2016). Although disheartening, these numbers are not unusual in the United States. Utah, which boasts of the country's largest number of dual-language programs, enrolls only 9\% of elementary students in dual-language programs (Harris, 2015). Throughout the United States, only 441 dual-language programs currently exist (Center for Applied Linguistics, 2014). In Nebraska, 76.8\% of English learners speak Spanish, 6.1\% Vietnamese, 3.3\% Nuer and 2.7\% Arabic (Center for Public Information, 2007). Despite the presence of this incredible linguistic variety, these languages are largely invisible and un-tapped in schools, when they could be incredible resources to the state and country at large.

Thus, this course was created as a space where (future) language teachers/educators could conceptualize multilingualism in alternative ways that 'allow human beings to interact on a more equal level, leading to greater harmony' (Agnihotri, 2014, p. 364). One of the activities in the course was a required language study and journal. Below is the description of the activity in the syllabus:

In order to gain a greater understanding of L3 and additional language learning and what language learners experience, it is necessary to undergo language study at the same time. Therefore, you are required to study a new language or refresh/update/improve your knowledge of an existing language. The way that you accomplish this is up to you. Some options include: self-study (with book or $\mathrm{CD}$, online video program), tutor, non-credit class, Duo Lingo language app, etc....In addition to studying the language, after your lesson, you are required to keep a journal that tracks your thoughts and reflections on this learning in light of your weekly readings. I will provide a format for the journal entries, but you are welcome to deviate from the format as you wish. So for 
example, if you are reading about language transfer, as you study your language that week, be cognizant of any language transfer issues that have occurred, and make a note of them in your journal. This is cumulative so for example if you studied language transfer two weeks ago but noticed something you did in your lesson two weeks later, of course you may comment on this whenever it occurs.

Interestingly, the class itself attracted multilingual students, only one of whom was an American citizen. All students had interest in issues of students affected by migration, some only because they were international students themselves, and others because they were teachers of English learners or foreign language teachers in the United States or in their home countries. For the purposes of this paper, two of the eight students became researcher/participants along with the first author (who was the instructor and course creator). The students - graduate research assistants of the first author during the time the course was taught, as well as students in the class

- were invited to participate in the research project after the course was completed.

\section{Findings}

Journals and collaborative discussion sessions led to important insights in the field of multilingualism that both support current research and open possibilities for future qualitative research in this area. The most significant research findings in multilingualism related to CLI.

\section{Contributions to CLI research}

The first CLI-associated theme is that of whether linguistic knowledge is integrated into a single lexicon or separated into two or more lexicons in the mind. To explain our support for theories of an integrated lexicon, we give an example from first author's Turkish language lesson reflection: 
First author (28.1.2015): When I saw müdür, which means manager, I somehow translated it as 'mother' even though I know that mother is anne in Turkish. Somehow the German mutter was in my mind, and interfered with me getting the right meaning. I believe this is because I had no idea what that word was, so I searched in my repertoire for something similar, and came up with the language I perceive to be similar. I believe part of this reason is because German is the only other language I know that uses the dieresis (or umlaut), so in my lexical recognition process, I believe that is why I searched in the German section of my brain, which is pretty limited.

Above, the author describes her thought process as she read but did not recognize a Turkish word. Since she was unable to find the word in her Turkish lexicon, her brain took the orthographic cue of the umlauts and led her (incorrectly) to find the German word mutter, which did not have umlauts - but did have some phonetic similarities to the Turkish müdür. This comment supports research (discussed earlier) demonstrating that in related languages (or languages perceived to be related), cognates have been found to trigger CLI (Nation, 1990). In addition, it supports recent work in the field that largely supports the idea of an integrated lexicon (Aronin \& Singleton, 2012; Canagarajah, 2011; Cenoz, 2013; Hall et al., 2009; Ruiz de Zarobe \& Ruiz de Zarobe, 2015). Below, the author discusses the process with the other researcher/participants: (observation notes, 12/9/2015)

First author: I first activated German because of the umlauts I saw, but then I heard the word in my head as I read the word and the sounds were similar to German too I think.

Third author: Not why did you go, but how did these factors enhance why you took the German words? You had two types of stimuli there....

First author: Müdür - I think I was imagining the pronunciation in my mind as I read it. Also, when I lived in Turkey, I met so many Turkish people that had lived in Germany at 
some point and many of them spoke German, so I have always seemed to link the two languages in my mind.

By talking through the process, first author was able to understand better what she had written, realizing that she had provided support for an integrated lexicon and models such as Dijikstra's (2003) multilingual activation model (MIA). According to the MIA, the above example demonstrates how different languages in the first author's linguistic system competed for meaning selection based on interlingual homographs and diacritical markers (Dijikstra, 2003, p. 18) as well as other societal factors linking the languages. Another important area of research that is supported by this journal excerpt is the fact that 'languages can influence target language development to a significant extent even when proficiency in the second language is low or intermediate' (De Angelis, 2007, p. 63). The fact that the first author only studied German for six months, her most recent experience happening two years before she began her renewed study of Turkish, provides support for studies, such as Flynn, Foley, and Vinnitskaya (2004), which argues that the language learning process is cumulative and, therefore, all the languages a speaker is familiar with can potentially influence language development.

Affective factors and CLI. Another sub-theme within CLI was that of affective factors and whether or not transfer occurred from a particular language. Below, second author (L1 = Marathi, Hindi and English, L3 = Chinese) talks about why she did not think her previously learned languages were influencing her learning of Chinese:

Second author (27/1/2015): I am currently learning Chinese, which was incidentally not on my list of languages-tolearn, probably because I have an irrational fear of learning the Chinese script or the Chinese characters. This led me to wonder whether a student's fears or desire or the lack of it to learn an additional language influences transfer in any way. I mentioned earlier that I do not think I am able to transfer much of my prior knowledge of languages to my acquisition of Chinese (at least not yet) because I think Chinese is greatly different from the other languages that I know. 
In the collaborative discussion of this comment, the authors talked about second author's language choice of Chinese and why she feared the script (observation notes 12/9/2015):

Third author: Would you have been excited to learn Chinese if it had a Roman script?

Second author: I'm terrified of the script. I chose Chinese because that was the language my tutor could teach me in exchange for me teaching her Hindi. I did not want to learn this language because I was afraid of the writing. So this is why I said to my tutor, let's just focus on spoken Chinese. Had I not had this convenient situation, I would have chosen to go ahead with Spanish because I had more experience with Romance languages because I spoke and had taught French.

The above comments relate to the idea of language distance (which we discuss below), but more relatedly, it illustrates how second author's fear of the Chinese script led her to disassociate it from any other language she knew, even though she could read Hindi and Sanskrit (written in the same script), which are very different from the Roman script she had learned in English, French and Spanish. Thus despite the common thought that polyglots such as second author always find language learning easy or at least think of themselves as good language learners, affective factors such as language anxiety can affect positive transfer and other areas of language learning all the same. This supports research mentioned earlier that provides evidence that FLA may increase even for polyglots that have learned multiple languages, such as second author (MacIntyre \& Gardner, 1991). Hence, teachers cannot assume that just because students know multiple languages that they will not have anxiety about learning a new one, especially when it involves a writing or sound system they perceive to be very different from what they already know. This leads us to the next sub-theme of linguistic distance and foreign language status/tagging for which we also found evidence supporting previous research.

Linguistic distance/foreign language tagging. Below, third author discusses how CLI of Spanish on her learning of French supports work in the areas of linguistic distance and foreign language status/tagging: 
Third author (30/1/2015): Basing his work on Levelt, De Bot (1992; as cited in De Angelis, 2007) suggests that bilinguals have a common store for their syllables. I wonder if the visual cues of a spelled out word trigger their Spanish pronunciation in my head because those letter combinations have already been stored in my brain as corresponding with a specific (Spanish) pronunciation. De Bot argues that L2 status and linguistic distance can also affect selection choices during production. These two factors may explain why I am more likely to rely on the Spanish pronunciation than an English one: I perceive the linguistic distance to be smaller between Spanish and French, and regardless of their actual linguistic distance (and vis-a-vis English to French), I view French through a foreign language lens.

Above, third author recalls that soon after her French lesson, she went to teach English and even though she had always called her student A:na, using English pronunciation, she noticed that she suddenly called her Ana, with a short vowel sound, which she had never previously done. Her findings about CLI occurring due to a perceived close linguistic distance support studies such as Kellerman (1983) on perceived language distance (i.e. perceived typological similarity) as it is used to explain CLI in production.

The excerpt also provides support for research on the association of foreignness (the cognitive association established between languages which are assigned the common status of 'foreign language' due to the fact that speakers studied these in foreign language contexts in school) such as De Angelis (2005) and Burton (2013) arguing that (in this case, lexical) CLI may be due to L2s/L3s being tagged as 'foreign'. During the collaborative discussion, third author realized that fluid movement across languages did not just involve lexical choices but also phonological ones. The following excerpts discuss the newly formed metalingual awareness that researcher/participants gained during the study and journaling:

Third author (12/9/2015): This 'short a' pronunciation of 'Ana' never happened until I started studying French. This made me more aware that code-switching isn't just with 
words, but can also be pronunciation. Since I have done the language study and journal, I do notice my own code-switching and CLI much more - I am much more aware of this process than I ever was before.

Second author: Yes, it [the language study and journal] has made me more aware of transfer and I have a hyper awareness - now I feel like I can't speak and I am editing and thinking about something all the time as I speak.

First author: I think that of all the times in my life, when we were doing the language journal, I was the most aware of what I was doing linguistically and how I was processing language. I was actually hyper-aware during this time.

Second author: Yes, I realize now that I am literally translating something, it makes sense but it's not commonly used. For example, I realize now that often I am influenced by the structure of English when I speak Hindi.

Third author: You probably were not aware before, but you were doing it.

The above findings illustrate the value that reflective journaling (and collaborative discussions) can have not only in understanding concepts related to the study of multilingualism but also the possibilities this type of qualitative research could add to quantitative studies on topics such as CLI. Looking at the above examples, and dialogs, it is easy to envision empirical studies in which participants are then asked to journal about linguistic choices they made and why they made them. In addition, we would recommend that more studies of multilingualism involve scholars and teachers in the field as participants. The journal excerpts above provide such rich data because the participants have the metalingual skills to talk about what they are discovering about their language learning and processing and can relate their findings to their own language teaching. This ability to articulate what is happening because of knowledge of the field could be an invaluable contribution that could increase empirical quantitative validity. 


\section{Contributions to language pedagogy}

Because the researcher/participants were also all language teachers, the study and journal activity led to new realizations on the part of the participants regarding the field of language pedagogy.

Metalingual awareness. The first finding in this area was revealed through a journal excerpt from first author in which she noted how she would have understood the concept right away had her tutor just mentioned that the structure in question was an object marker:

First author (11/2/2015): I think I saw how my metalinguistic awareness really helped me because my tutor did not know how to explain to me the object (dative) ending that I needed to show the word was the object in the sentence. Once he used the word 'object' I got it and was able to understand, but I think other learners that weren't familiar with the concept of object markers would have had a hard time.

This realization highlights the fact that language teachers do not always have the language needed to talk about the structures they are teaching, but also, some language learners (especially multilinguals who have formal experience learning multiple languages) do, and want help facilitating their language learning through the transfer of similar concepts. When discussing this with the other researcher/participants (12/9/ 2015), third author noted that many pre-service teachers in the United States lack metalinguistic awareness about grammar because they are not taught this terminology in school. That is, multilingual students in the United States are coming from places where they have more experience with the learning of names for linguistic structures (such as object/subject) and words to talk about language than US teachers. This underscores the need for explicit teaching of language structure (to pre-service teachers) in the United States so that when students want to know these things (and their language learning could be facilitated through their metalinguistic awareness), teachers have the tools to teach them.

In addition to realizing the importance of giving language teachers the tools to talk about language, many examples were found regarding 
multilingual pedagogies. The following excerpt illustrates how second author used her student's L2 knowledge of Japanese to facilitate the student's positive transfer to Hindi:

Second author: When I taught greetings and salutations in Hindi, my colleague compared the structure of the questions to the form used in Japanese greetings, which is a language that she had studied a few years ago. In fact, since I am also familiar with basic Japanese and remember the greetings, it made the process of explaining the question easier.

In reflecting on how she gave examples of Japanese to her student in order to help her understand Hindi, second author remarks that:

Second author (12/9/2015): When I was learning to teach languages, we were told not to use any other language. It was recommended to teach only the one language, no mixing but I think, on the sly, all teachers used to try and make connections to Hindi or English and we shouldn't have to be sly about it, we should be encouraged to use these strategies.

This comment highlights teacher training that failed to recognize multilinguality and the fluid hybrid language practices in which multilinguals commonly engage. Courses such as the one for this study helped second author realize how she engaged in these practices to help her students and she was able to see the value in doing so even though she had been told this was not good practice.

Social justice and the creation of empathy. A final sub-theme in multilingual pedagogy related to issues of social justice, many of which dealt with empathy for students such as in this example:

First author (11/3/2015): I also noticed that I started giving up on understanding toward the end. This makes me consider the length of the lessons my students teach and the $100 \%$ target language rule. A 50 minute lesson seems to be about the right length, which makes me think about block lessons which are very long. I'm no longer sure that is feasible for language classes, although I suppose what happens 
is they work on projects and other things that don't mean they are taking in new information. This week I read Cummins (2005, 2009) articles regarding multilingual pedagogies and the use of L1 and I am beginning to really agree with him even in contexts that are not minority language. There just are so many uses for bringing in the students' other languages if it is possible.

Besides connecting the overwhelming feeling of being submersed in a language to minority language learners, the above comment questions the switch to block scheduling for some schools in the United States in which students have two simultaneous hours or longer dedicated to one subject. Later, the same author also made this similar comment in which she experienced increased empathy for minority language learners in dominant language environments. In the article she references, the authors described in detail the painful experiences of students in Arizona who were forced to attend school and participate in all events without any access or acknowledgment of their L1s:

First author (19/2/2015): I thought about Combs, Evans, Fletcher, Parra, and Jiménez (2005) because as I was trying to process such quick speech from my tutor. I could imagine the students from the Combs' article trying every day, all day to learn when the language was sped up like that. No wonder students give up. They are told they are failures from the beginning, and there is no hope because they are not given the aids that they need to succeed such as I had. My tutor would repeat for me, slow down his speech, use visual aids or sometimes go back to English. The teachers in the Combs et al. article could not do most of these things.

Third author also experienced this renewed empathy for her students as she talks about her own language learning circumstances and how they affected her learning of French:

Third author (24/1/2015): This is the first time that I have tried to learn a language without first being exposed to it passively. This is also the first time that I have tried to learn 
a language without a human interlocutor or a formalized program of study. And this is the first time that I have tried to learn a language late at night, whispering it into a phone so that I don't wake the children sleeping next to me. I find myself forgetting simple grammatical concepts and vocabulary words, and I cannot help thinking about my adult English learners who work physically demanding full time jobs, care for family members, worry about paying bills, and deal with other stressors which must make the cognitive load of trying to learn a new language almost unbearable at times. These are not new thoughts for me, but this language study is also an exercise in empathy...If I cannot remember whether chat takes le or la, can I be surprised when my students forget whether book titles are italicized or underlined according to the MLA? And, even with this pondering, how can I still hold them to a standard which will encourage and assist them to grow as language learners and users of an academic dialect?

She later relates this to issues of motivation and language learning circumstances of her English reading/writing student:

Third author (21/2/2015): Every week I meet with Khalaf, a Yazidi refugee from Iraq, who is attempting an intense combined developmental English reading/writing course while working 55-6o hours a week to send money to his family in Syria....College is a dream for Khalaf, an enjoyable challenge, but acquiring academic English is not a priority for him. Providing for his family is Khalaf's true purpose for living and where he spends the vast majority of his waking time and energy. I feel like I should not compare Khalaf's situation with my own, but when I sat down to write about my language study this week, I could not help think of Khalaf, who like all students, myself included, had noble intentions and an interest in learning, but also a full time job and a family to worry over and provide for.

Second author also made several realizations about social justice and language education through the journaling. Because she did not 
feel that she had a choice - she had to learn a language as part of the class, and she felt forced into learning Chinese because that was the language her classmate could provide, she was able to empathies with students in tribal communities in India who are forced to learn English upon entering school:

Second author (10/3/2015): Had it not been a requirement of this course to learn a new language and had I chosen to continue studying Spanish or selected another romance language, I may not have ever really got a feel of the struggles of the children who are forced into the submersion model. The studies in Mohanty, Kumar Mishra, Upender Reddy, and Ramesh (2009) on children from tribal communities in the two Indian states of Andhra Pradesh and Orissa also made me aware of some of the nascent measures against linguistic genocide that are being taken in my home country to reduce the gap in the power relations between languages and therefore implicitly, the speakers of these languages.

When reflecting on this comment in the collaborative discussion, she explained:

Second author (12/9/2015): I have always been in a situation of privilege - that is, I chose my languages. In this case, I didn't want to learn Chinese but was compelled to learn it and I therefore experienced FLA (Foreign Language Anxiety) (Dewaele \& Oudenhoven, 2009) and an irrational fear. This made me think of other students. That is, I had always wanted to learn my languages and had some familiarity with them, but not wanting to learn Chinese, I could now imagine that for a tribal student put in an English classroom, that must be really terrifying.

Third author: Right, because you could say 'I'm never going to learn Mandarin again', but they don't have a choice.

Thus, being forced into learning a particular language helped second author empathize with students whose language of instruction is not one of their home languages. 


\section{Discussion/conclusion}

This study has demonstrated that reflective practices such as journaling and collective autoethnography undergone by language teachers/ researchers engaged in language study can provide important qualitative support for quantitative studies in the field of multilingualism. Important findings included support for an integrated lexicon, affective factors such as FLA and how they affect transfer and support for multilingual research investigating linguistic distance. We recognize that a small sample of journal entries of three language teachers and their ensuing discussions about the process does not allow for generalizability. However, we believe that this study has the potential to provide stimulus for a profound understanding of our effort of language study and reflection and to open new intellectual avenues through uniquely personal meaning and empathy. Our study contributes to current findings in multilingualism research by providing support for existing models. In addition, the study reveals how CAE could lead to further discoveries that support more quantitative work. We believe these findings are just the beginning of the possibilities that could arise for multilingual research through this type of collaborative reflective methodology. Hence, we envision for future multilingual research a space for the research methodology of language study/ journaling combined with CAE to be used as a qualitative measure to complement quantitative studies in these areas.

In addition, this study provided a space for language teachers to make important realizations regarding language pedagogy such as the increased need for metalingual awareness in language teachers and all teachers of multilingual students, the need to consider individual motivation, learning circumstances and the amount of time we are asking students to live only in the target language as well as the empathy that can be created for language students, in particular, language learners with minority home languages. Furthermore, activities such as critical reflective journaling and collaborative discussions about the journals can lead to support for multilingual pedagogies, which must be brought to the forefront as more classrooms include multilingual learners. In the future, we hope that participation in studies such as these as part of language teacher education will increase participants' sensitivity and attention to linguistic and cultural diversity as they exist within the classroom while providing language teachers 
with a 'multilinguality perspective' that treats the multilingual nature of learners as a resource for ongoing linguistic and cognitive growth (Agnihotri, 2014). Finally, although this work largely addressed the language education situation in the United States, these findings are applicable worldwide, and we hope that they will inspire more multilingual pedagogies and ways of thinking about multilingual (immigrant) students that recognize and value the languages they live and function with in their daily lives. Furthermore, we hope that language educators and researchers who read this study will recognize the value of reflective practices that allow them to reflect on their own language learning and apply this new knowledge and empathy to their teaching.

Disclosure: The authors report no potential conflicts of interest.

\section{References}

Agnihotri, R. K. (2014) Multilinguality, education and harmony. International Journal of Multilingualism, 11(3), 364-379. doi:10.1080/14790718.2014.921181

Akbari, R. (2007). Reflections on reflection: A critical appraisal of reflective practices in L2 teacher education. System, 35(2), 192-207.

Aronin, L., \& Singleton, D. (2012). Multilingualism. Amsterdam: John Benjamins Publishing.

Burton, G. (2013). Cross-linguistic influence in non-native languages: Explaining lexical transfer using language production models. International Journal of Multilingualism, 10(1), 46-59. http://dx.doi.org/10.1080/14790718.2012.6792 74

Canagarajah, S. A. (2011). Codemeshing in academic writing: Identifying teachable strategies of translanguaging. The Modern Language Journal, 95(3), 401-417.

Cenoz, J. (2013). Defining multilingualism. Annual Review of Applied Linguistics, $33,3-18$.

Cenoz, J., Hufeisen, B., \& Jessner, U. (2001). Crosslinguistic influence in third language acquisition: Psycholinguistic perspectives. Clevedon, UL: Multilingual Matters.

Center for Applied Linguistics. (2014). Directory of two-way immersion programs in the U.S. Retrieved from www.carl.org/twi/directory

Center for Public Information. (2007). Top five languages by state. The center for public information. Retrieved from http://www.centerforpubliceducation.org/ Main-Menu/Instruction/What-research-says-about-English-language-learnersAt-a-glance/Top-five-languages-by-state.html\#sthash.gjae2tFJ.dpuf 
Chang, H. (2013). Chapter 3: Individual and collaborative autoethnography as method. In S. Holman Jones, T. E. Adams, \& C. Ellis (Eds.), Handbook of autoethnography (pp. 107-119). Walnut Creek, CA: West Coast Press.

Chang, H., Wambura Ngunjiri, F., \& Hernandez, K. C. (2013). Collaborative autoethnography. Walnut Creek, CA: Left Coast Press.

Cohen, A. D. (1995). In which language do/should multilinguals think? Language, Culture and Curriculum, 8(2), 99-113.

Combs, M. C., Evans, C., Fletcher, T., Parra, E., \& Jiménez, A. (2005). Bilingualism for the children: Implementing a dual-language program in an English-only state. Educational Policy, 19, 701-728.

Cummins, J. (2005, September 23). Teaching for cross-language transfer in dual language education: Possibilities and pitfalls. TESOL symposium on dual language education: Teaching and learning two language in the EFL setting. Bogazici University, Istanbul, Turkey.

Cummins, J. (2009). Fundamental psychological and sociological principles underlying educational success for linguistic minority students. In T. SkutnabbKangas, R. Phillipson, A. Mohanty, \& M. Panda (Eds.), Social justice through multilingual education (pp. 19-35). Bristol, CT: Multilingual Matters.

De Angelis, G. (2005) Multilingualism and non-native lexical transfer: An identification problem. International Journal of Multilingualism, 2(1), 1-25.

De Angelis, G. (2007). Third or additional language acquisition (Vol. 24). Bristol: Multilingual Matters.

Dewaele, J. M., \& Oudenhoven, J. P. (2009). The effect of multilingualism/ multiculturalism on personality: No gain without pain for Third Culture Kids? International Journal of Multilingualism, 6(4), 443-459.

Dijikstra, T. (2003). Lexical processing in bilinguals and multilinguals: The word selection problem. In J. Cenoz, B. Hufeisen, \& U. Jessner (Eds.), The multilingual lexicon (pp. 11-26). Dordrecht: Kluwer Academic Publishers.

Education Bug. (2016). Nebraska public schools statistics. Education Bug. Retrieved from http://nebraska.educationbug.org/public-schools/

Ellis, C. (2009). Revision: Autoethnographic reflections on life and work. Walnut Creek, CA: Left Coast Press.

Ellis, C., \& Bochner, A. P. (2000). Autoethnography, personal narrative, and personal reflexivity. In N. K. Denzin \& Y. S. Lincoln (Eds.), Handbook of qualitative research (2nd ed., pp. 733-768). Thousand Oaks, CA: Sage.

Farrell, T. S. (2011). Exploring the professional role identities of experienced ESL teachers through reflective practice. System, 39(1), 54-62.

Farrell, T. S. (2013). Teacher self-awareness through journal writing. Reflective Practice, 14(4), 465-471.

Farrell, T. S. C. (2007). Reflective language teaching: From research to practice. London: Continuum Press.

Flynn, S., Foley, C., \& Vinnitskaya, I. (2004) The cumulative-enhancement model of language acquisition: Comparing adults' and children's patterns of development in first, second and third language acquisition of relative clauses. International Journal of Multilingualism, 1(1), 3-16. 
de Groot, A. M. B. (1992). Determinants of word translation. Journal of Experimental Psychology: Learning, Memory and Cognition, 18, 1001-1018.

Hall, C. J., Newbrand, D., Ecke, P., Sperr, U., Machand, V., \& Hayes, L. (2009). Learners' implicit assumptions about syntactic frames in new L3 words: The role of cognates, typological proximity, and L2 status. Language Learning, 59(1), 153-202.

Harris, E. (2015, October 8). Dual language programs on the rise, even for native English speakers. The New York Times. Retrieved December 15, 2015 from http://www.nytimes.com/2015/10/og/nyregion/dual-language-programs-areon-the-rise-even-for-native-english-speakers.html? $\mathrm{r}=\mathrm{O}$

Johnson, E. (2005). Proposition 203: A critical metaphor analysis. Bilingual Research Journal, 29(1), 69- 84.

de Jong, E. J. (2013). Policy discourses and U.S. language in education policies. Peabody Journal of Education, 88(1), 98-111.

Jorden, E. H., \& Walton, R. A. (1987). Truly foreign languages: Instructional challenges. Annals of the American Academy of Political and Social Sciences, 490, 110-124.

Kellerman, E. (1979). The problem with difficulty. Interlanguage Studies Bulletin, 4, 27-48.

Kellerman, E. (1983). Now you see it, now you don't. In S. Gass \& L. Selinker (Eds.), Language transfer in language learning (pp. 112-134). Rowley, MA: Newbury House.

Keshavarz, M. H., \& Astaneh, H. (2004). The impact of bilinguality on the learning of English vocabulary as a foreign language (L3). Bilingual Education and Bilingualism, 7, 295-302.

Klein, E. C. (1995). Second versus third language acquisition: Is there a difference? Language learning, 45(3), 419-466.

Kroll, J. F., \& Stewart, E. (1994). Category interference in translation and picture naming: Evidence for asymmetric connections between bilingual memory representations. Journal of Memory and Language, 33, 149-174.

Liddicoat A. J., Heugh, K., Jowan Curnow, T., \& Scarino, A. (2014). Educational responses to multilingualism: An introduction. International Journal of Multilingualism, 11(3), 269-272. doi:10.1080/14790718.2014.921174

Loughran, J. (2002). Effective reflective practice: In search of meaning in learning about teaching. Journal of Teacher Education, 53, 33-43.

MacIntyre, P. D., \& Gardner, R. C. (1991). Language anxiety: Its relationship to other anxieties and to processing in native and second languages. Language Learning, 41, 513-534.

Mann, S. (2005). The language teacher's development. Language Teaching, 38, 103-118. doi:10.1017/So261444805002867

McCarty, T. (2004). Dangerous difference: A critical-historical analysis of language education policies in the United States. In J. W. Tollefson \& A. B. Tsui (Eds.), Medium of instruction policies. Which agenda? Whose agenda? (pp. 7193). London: Routledge. 
Mohanty, A., Kumar Mishra, M., Upender Reddy, N., \& Ramesh, G. (2009). Overcoming the language barrier for tribal children: Multilingual education in Andhra Pradesh and Orissa, India. In T. Skutnabb-Kangas, R. Phillipson, A. Mohanty, \& M. Panda (Eds.), Social justice through multilingual education (pp. 283-300). Bristol, CT: Multilingual Matters.

Nation, I. S. P. (1990). Teaching and learning vocabulary. New York, NY: Newbury House.

Odlin, T. (2003). Cross-linguistic influence. In C. J. Doughty \& M. H. Long (Eds.), Handbook of second language acquisition (pp. 436-486). Malden, MA: Blackwell.

Pandya, C., McHugh, M., \& Batalova, J. (2011). Limited English proficient individuals in the United States: Number, share, growth, and linguistic diversity. LEP Data Brief. Retrieved from http://www.migrationinformation.org/ integration/LEPdatabrief.pdf

Pauwels, A. (2014). The teaching of languages at university in the context of super-diversity. International Journal of Multilingualism, 11(3), 307-319. doi:10 .1080/14780718.2014.921177

Ricento, T. (2005). Problems with the 'language-as-resource' discourse in the promotion of heritage languages in the U.S.A. Journal of Sociolinguistics, 9(3), 348-368.

Richards, J. C., \& Lockhart, C. (1994). Reflective teaching in second language classrooms. New York, NY: Cambridge University Press.

Ringbom, H. (2001). Lexical transfer in L3 production. In J. Cenoz, B. Hufeisen, \& U. Jessner (Eds.), Crosslinguistic influence on third language acquisition: Psycholinguistic perspectives (pp. 59-68). Clevedon: Multilingual Matters.

Ruiz, R. (1984). Orientations in language planning. The Journal for the National Association of Bilingual Education, 8(2), 15-34.

Ruiz de Zarobe, L., \& Ruiz de Zarobe, Y. (2015). New perspectives on multilingualism and L2 acquisition: An introduction. International Journal of Multilingualism, 12(4), 393-403. doi:10.1080/14790718.2015.1071021

Saito, Y., \& Samimy, K. K. (1996). Foreign language anxiety and language performance: A study of learner anxiety in beginning, intermediate, and advanced-level college students of Japanese. Foreign Language Annals, 29(2), 239-249.

Saldaña, J. (2013). The coding manual for qualitative researchers (2nd ed.). London: Sage.

Schildkraut, D. J. (2001). Official-English and the States: Influences on declaring English the official language in the United States. Political Research Quarterly, 54(2), 445-457.

Valdez, V. E., Delavan, G., \& Freire, J. A. (2014). The marketing of dual language education policy in Utah print media. Educational Policy, 1-35. doi:10.1177/o895904814556750 